\title{
Napoleon i jego wojska w oczach Mazurów
}

Zbigniew Chojnowski 


\section{Zbigniew Chojnowski}

\section{Napoleon i jego wojska w oczach Mazurów}

$\mathrm{M}$ azurzy, mimo że władali mową polską, nie podzielali wspólnych poglądów na historię z Polakami. Byli bowiem poddanymi króla pruskiego i utożsamiali się z racją stanu Prus (Mazurzy nazywali siebie „Staroprusakami”, „Prusakami”). Dlatego ich postrzeganie osoby Napoleona, jego działań i wojsk zbiegało się z prusko-niemiecką interpretacją dziejów. Nie do końca można się zgodzić z opinią, że w mazurskim piśmiennictwie XIX w. uprawiana była jedynie „czarna legenda Napoleona”.

O francuskim cesarzu i wojnach przez nicgo wywołanych najwięcej napisał „ojciec mazurskiej literatury ludowej”, a zarazem najpłodniejszy pisarz mazurski XIX w. - Marcin Gerss (1808-1895). W wydawanym przez siebie „Kalendarzu KrólewskoPruskim Ewangelickim” zamieścił dziesiątki artykułów i wierszy o „wojnie nieszczęśliwej", jak nazywano batalie i różne konflikty francusko-pruskie z lat 1806-1807, a także o innych zdarzeniach związanych z późniejszym okrescm napoleoniskim w dziejach Prus, zwłaszcza „wojną wyzwoleńczą” z lat 1813-1815. Większość tych tekstów zebral Grzegorz Jasiński i opublikował w książce O Napolconie', niészcz̧słiu'cj u'ojnie, dzie'jach europejskich i pruskich (Olsztyn 1997). Jak twierdzi Jasiński, „To, ze Marcin Gerss poświęcił tak wiele miejsca w swoich kalendarzach wojnom napoleonískim, wynikało także $z$ wiedzy i tradycji historycznej istniejącej w drugiej polowie XIX wiekı na Mazurach”, kiedy to „w przekazie ludowym dominowaly [...] wydarzenia z wojen napoleońskich". W mazurskich pieśniach ludowych odbijają się nie tylko ich echa, ale zapamiętany i opisywany jest ich przebieg, jak w wielozwrotkowym tekście zaczynającym się od słów „Wy gburzy, kelmrzy, ziemiänie”, w którym m.in. czytamy: 
W roku tysiąc osiemset ósmym

Urosła biada i z kosmem

W Prusicch bez Bonapartego

Carta krola francuskiego.

Ten w pruski ląd wmasierował,

Pieniędzami pobrakowal,

Obdzierał ląd z brantsiosami [kontrybucjani]

A w ostatkı brali sami.

Bojal sie pruskich zołnierzy,

Ale pruskie oficerzy

Na jego wolo przystali,

Podkupkie² od niego brali.

Bohaterem pozytywnym tej mazurskiej rymowanej opowieści jest król pruski Fryderyk Wilhelm III (jego nieudolność i podwójną grę wobec Napoleona pominął lub wybielił również Marcin Gerss) i jego małżonka Luiza, zaś czarnym charakterem „Francuz”, który w Rosji poniósł sromotną karę między innymi za brak szacunku do chleba:

Francuscy chleb miatki, rzanny [pszenny]

W Prusiech po ziemi miotali,

Ale go w Moskwie taknęli,

Bo Boga tem rozgniewali'.

Zwycięska dla Prus wojna z Francją z lat 1870-1871 byla dogodnym dla propagandy pruskiej wydarzeniem, aby obudzić (lub uformować) w Mazurach pamięć o militarnych i niemilitarnych zmaganiach z wojskiem napoleońskim, a przede wszystkim o klęsce Napoleona i jego armii. Nie pozostawila ona na „ziemi pruskiej” dobrych wspomnień. Jan Donder z Lipińskich, pisząc jako uczestnik wojny 1870 z „kwatery” w Bouvais, przypominat:

Powiem wam o wojnie z tym Francuzem srogim,

Który zawsze bywał nam największym wrogiem.

$\therefore$ podkupkà - lapówka.

"Pieśni guminne ludu mazurskiego u' Prusach Wschodnich, w: W. Kętrzyński, O Mazurad, wyb. i oprac. J. Jasiniski, Olsztyn 1968, s. 92-96. 
Donder wspomina zwycięskie potyczki i bitwy Prusaków z Francuzami, np. pod Wyszemborkiem - o nich samych zaś pisal, że plądrowali, kradli, gwałcilit (Donder ubolewał nad tym, że żohnierze pruscy we Francji w wojnie 187()-1871 wobec ludności cywilnej zachowywali się podobnie). Wspomnienie tamtych wydarzeń wzmacniało wolę walki i triumf militarno-polityczny.

Niepochlebny, wręcz odpychający, wizerunek Napoleona wyrysował jeden z pierwszych mazurskich wierszopisów - „gospodarz i radca kościelny” — Frycz Olszewski z Różyńska (powiat Jańsbork [Johannisburg], współcześnie Pisz). Ten ludowy poeta francuskiego cesarza porównał do biblijnego faraona, który z powodu zatwardziałego serca nie clıciał dopuścić do wyjścia Żydów z Egiptı:

\author{
Pysznego Napoleona \\ Z Twoją pojmalim pomocą. \\ Boś Ty go, jak Faraona, \\ Pokarał z całą jego mocą. \\ Tak z nim, Panie uczyniteś \\ I wojska jego pobileś \\ I jego kraj strwożyleśs.
}

W XIX w. najbardziej barwny i motywowany wiedzą historyczną portret Napoleona i jego wojsk powstał pod piórem Marcina Gerssa, który o intencjach i sposobie ujęcia tematu pisal:

Choć Napoleon był wielkim wrogiem naszym, to jednak musi ten, co historię o nim pisze, czytelnikom swoim prawdę powiedzicć. A tak musiemy i Napoleonowi przyznać to, co dobrego on sprawil, wspominając i na zle sprawy jego".

Mazurski autor przytoczył list „królowej pruskiej Ludwiki” z 1808 r., w którym stwierdziła, że Prusy po śmierci Fryderyka Wielkiego przestały się rozwijać. Dopiero procesy wzbudzone przez Napoleona przyniosły poprawę; pisała:

+ J. Donder, O uojnic między' Nicmanmi i Francuzami r. 1870 i 1871. KKPE 1873, s. 49-52. Zob. też

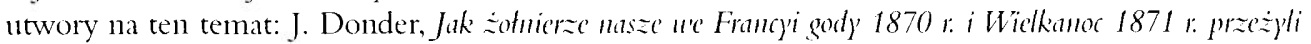
[utwór napisany 22 kwietnia 1871 r. w Bouvais]. KKPE 1872, s. 129-130; M. Gerss, Pocmat o wojnic, KKPE 1872, s. 140-144; J. Donder. O wojnie roku 1870 i 71 [tekst przyslany z Francji przez autora: „syna gospodarskiego w Lipińskich w parafii kluskiej, dnia 1 marca 1871], KKPE 1873, s. 126-128; M. Gerss, Modlitu'u ma Nou' ' Rok, KKI'E 1873, s. 3.

${ }^{5}$ F. Olsiewski [wzgl. Olszewski]: Dziq̨ki za pokój przy'urócony. KKPE 1872. s. 130-131.

'M. Gerss, O Napoleonic..., op. cit., s. 4(). 
Od cesarza francuskiego wiele się nauczyć możemy. I nie zaginie to nigdy, co on uczynil. Zapewne jest on statkiem ${ }^{7}$ w ręku Wszechmocnego, aby zestarzałe rzeczy, już żadnego znaczenia nie mające, były pogrzebione ${ }^{8}$.

Gerss nie taił, że „nieszczęśliwa wojna” wywołała konieczność reform, które przeksztalciły Prusy. Jak wiadomo, państwo to zmieniło się z monarchii absolutystycznej w monarchię konstytucyjną". Nie bez związku z wojnami napoleońskimi pozostaje fakt, że o Mazurach jako odrębnej społeczności zaczęto mówić w Prusach właśnie tuż po 1815 r., a więc w wyniku następstw procesów wywolanych przez Napoleona Bonaparte" (A. Kossert).

Napoleon „Bonepart”, jak pisał o cesarzu Francji pruski Mazur, był „tęgim wojakiem" obarczonym mnóstwem przywar. Składał puste obietnice ${ }^{11}$, czego przykladem wedlug Gerssa było oszukanie Polaków ${ }^{12}$, którzy „byli najtęższymi wojownikami w wojsku francuskim"13. cechowała go nieokiełznana żądza władzy, obsadzał stanowiska członkami swojej rodziny i przyjaciółmi, posługiwał się przekupstwem, dzięki czemu bez walki lub bez większego trudu podbił Prusy, uprawial czarną propagandę przeciw swoim wrogon, miał „nieszlachetne serce”|'. Przy różnych okazjach Gerss wskazywał na te i inne wady Napoleona. Mimo że byl

największym wojakiem i najpotężniejszym monarchą czasu onego. I wykonał nawet wiele dobrego. Ale był przy tem wyniosłym, bardzo często nie dotrzymal słowa, będąc nierzetelnym i panowania chciwym. Czy miał przyczynę zaczynać wojnę z Prusami i stać się przyczyną tak wielkiego krwi przelania i tak wielu strat niewypowiedzianych. Chcial króla do zawarcia pokoju nakłonić; ale gdy król na to chciał przystać, to począł wykrętami gadaćl ${ }^{5}$.

Gerss nie omieszkal wskazać na to, że w postępowaniu i decyzjach Napoleona są i te, które warto naśladować. Przy tej okazji podawane są niekiedy wypowiedzi Napoleona sformułowane w polszczyźnie mazurskiej. Jedna z nich pokazuje cesarza jako tego dowódcę, który potrafił docenić żołnierzy i „pobudzać do waleczności”. Napoleon 2 grudnia $1806 \mathrm{r}$.

'statek' - narzędzie.

M. Gerss, O Napoleonic..., op. cit., s. 105.

Zob. S. Salmonowicz, Prusy. Dzieje państu'u i spoteczeństu'a, Warszawa 2(K)4, s. 236 i nast.

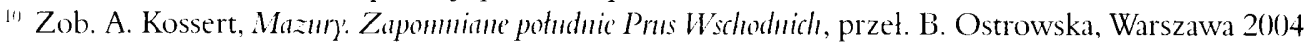

— zob. rozdziat Poustajg, "Mazun" (1815-1871)", s. 95-140.

M. Gerss, O Napoleonic..., op. cit., s. 59.

12 Ibidem, s. 58.

13 Hide'm, s. 214.

it Midem, s. 65.

Ibidcm, s. 99-100. 
odezwał się [...] do wojsk swoich: „Żołnierze! - tak zawołał - Już prawie rok temu, jakeście na wiekopomnem polı bitwy pod Sławkowem (Austerlitz) z nieprzyjacielem się bili. Zestraszone bataliony rosyjskie pouciekaly w zamieszaniu, albo pooddawali, gdy je otoczono, broń swoję""s.

Gerssowi imponowało to, że „Bonepart” uświetniał zołnierzy, którzy polegli za niego, stawiając im pomniki ${ }^{17}$. W dziewiętnastym wieku i później (do roku 1945) na obszarze Mazur był zwyczaj upamiętniania najwyższych dowódców, jak i prostych żohnierzy, np. w kościołach umieszczano tablice z ich nazwiskami, stawiano pomniki zwycięstwa. W kościele w Pasymiı do dziś zachowały się tablice z nazwiskami mężczyzn z parafii pasymskiej, którzy zginęli w bitwach z czasów napoleońskim.

Gerss z uznaniem podaje, że, wzorując się na stosunkach w wojskach Francuzów, pruska władza zniosła kary cielesne; burzyła się przeciwko temu szlachta i kadra oficerska, ale zakazano „biegania przez rózgi i bicia żołnierzów kijami”"

Marcin Gerss powraca kilka razy do sprawy zniesienia poddaństwa, „starego kwasu” Prus, którego wyczyszczenie nastąpilo dziçki wplywowi Napoleona w $18(17$ r. Mazurski pisarz podawal:

wydano ustawy, podług których gburzy ${ }^{\text {k" }}$ się stali wlaścicielami swoich posiadłości. A to było sprawą mądrą, bo stan gospodarski ma wielkie znaczenie.

Napoleon tak twierdził o gburach: „Gburzy są jądrem narodu. Wojska rzeczpospolitej, w których najwięcej było dziatek stanu gospodarskiego, bojowaly zawszedy ${ }^{21}$ mężnie z nieprzyjaciółmi swoimi i wyratowały ojczyznę naszą z biady i napaści nieprzyjacielskiej. A z tej przyczyny są gburzy godnymi tego, abyśmy stan ich mieli w uczciwości ${ }^{21}{ }^{1,22}$.

Zwrócenie się władcy ku „ludowi” Gerss ocenia bardzo wysoko i jako posunięcie, które osłodziło sromotny koniec Napoleona. Gdy zerwal z „ludem”, poniósł klęskę:

Doznał się sam tego, gdy go na ostrów Helenę wygnano. Tam powiedział: „Wysocy panowie odwrócili się ode mnie, gdym był w nieszczęściu.

\footnotetext{
15 Ibidem, s. 60.

17 Tamże.

is Ibidem, s. 110.

in 'gbur' - chlop, rolnik.

211 'zawszedy' - zawsze,

21 'mieć w uczciwości' - szanować, cenić.

I2 M. Gerss, O Napoleonic..., op. cit., s. 109.
} 
I nie mogłem się spuścićc ${ }^{23}$ na szlachtę, ani na marszalków moich, ale lud i wojsko były na mojej stronie"-2t.

Podkreślanie roli „ludu” przez Gerssa tlumaczyło się także tym, że swoją opowieść O Napoleonic, nieszczesstiu'ej urojnic, dziejach europejskich i pruskich adresował do wiejskich nauczycieli, rzemieślników i rolników. Sam przecież wywodził się z chłopskiej rodziny spod Gołdapi. Wieloletnie pisanie o epoce napoleońskiej wiązało się z jego dzieciństwem - w roku upadku Napoleona miał siedem lat, a także z tym, że do Wiosny Ludów, czyli do roku 1848 - spoleczna pamięć o niej wśród Mazurów była żywa i stanowiła element kształtowania się ich świadomości historycznej, patriotyzmu pruskiego oraz poczucia przynależności do „narodu pruskiego”.

Gerss, pisząc o Napoleonie, odwolywal się do wyobrażeń i świata wartości charakterystycznych dla pruskich Mazurów. Np. sposób opisania pobytu Bonapartego w Dreźnie w lipcu 1807 r. nie dość, że ma pewien walor satyryczny, to odnosi się do niechęci Mazurów do strojenia się (skromność w ubiorze to jeden z tematów dziesiątków wierszy mazurskich). Toteż musiała przypaść do gustu Mazurom scena pojawienia się Napoleona na dworze saskim. Gerss budowal w niektórych miejscach swojego tekstu przesłanki, które umożliwić mogly wzbudzenie sympatii Mazura do cesarza Francuzów, a to po to, aby wzmocnić poglądy upowszechniane przez autora. Nić porozumienia między Mazurami i Napoleonem w omawianym fragmencie jest przygotowaniem do wypowiedzenia myśli, że „Bonepart” burzył się przeciw papieżowi. Gerss bowiem jako luteranin w Prusach Wschodnich czul się misjonarzem ewangelicyzmu i jego obrońcą na wschodnich rubieżach, i gdy tylko znajdował okazję, polemizował z ideą papieskiego zwierzchnictwa. Jak przemycil treść światopoglądową, ilustruje fragment poniższy:

Przybywszy do Drezna, [Napoleon] stanął w pałacu króla saskiego. Nazajutrz zgromadzili się dworzanie i dworzanki, i najwyższa szlachta w pałacu królewskim na przedstawienie cesarzowi. Ale byli przyodziani po staremu. Panowie byli w czerwieni i pudrowani, mając nawet woreczki do pudru przy sobie, a damy miały na sobie starodawną obletę $e^{25}$ [ubranie] i suknie z krynoliną. Ledwie co ich Napoleon zobaczył i przybiór ich, to zawołał: „Toć to cała komedia po małpowsku!” I usłyszeli wszyscy słowa jego. I poodrzucali nazajutrz obletę od potopu świata i przybyli w odzieniu czasu onego zwyczajnem.

\footnotetext{
23 'spuścić się" - polegać (na kimś, na czymś).

${ }^{2+}$ M. Gerss, O Vapoleonic'..., op. cit., s. 109.

25 'obleta' - ubranie, strój.
} 
Dnia 22 lipca [1807] urządziło duchowieństwo wielkie i uroczyste nabożeństwo w kościele katolickim i zaprosili nań i Napoleona I. I czckali, i czekali na niego, ale daremnie. Albowiem prawie ${ }^{26}$ tejże godziny przepowiada ${ }^{27}$ pisarzowi swojemu list przeciw papieżowi ostry. Bo miał za $\mathrm{co}^{28}$.

Na tym Gerss kończy, bo uważa, że nie musi Mazurom tłumaczyć, o co bliżej chodzi. To, co opisal, zalicza do „dobrych spraw Napoleona”.

Ceni go, gdy lapidarnie odnotowuje jego odwiedziny w Weimarze u Goethego:

Napoleon, pan bardzo mądry, wiedząc, że poeci mają wielki wpływ na lıd, przedsięwziąl z Gietem i Wylandem mieć pogadankę.

Spotkanie miało dowieść tego, że Napoleon ,jest głęboko uczony”끄.

Gerss zawiązuje między Mazurami i Napoleonem sympatiç, sugerując, że cesarz rzekomo interesował się poddanymi króla pruskiego. Kiedy naczelny wódz armii francuskiej przed wyprawą na Rosję w 1812 r. rezydował w Gąbinie, rozmawiał z tamtejszym prezydentem, a równocześnic wplywowym politykiem pruskim, I Ieinrichem Theodorem von Schönem o historii Prus, a w tym o Mazurach, nazywanych tu „starymi Prusakami"; miał dopytywać się

o okoliczności zawojowania Prus przez Krzyżaków, twierdząc mylnie, że starzy Prusacy należeli do plemion Łotyszów (Letten) i że więc byli plemienia pierwotnego. [...]. Dalej oświadczył Napoleon, że mu kraj i lud pruski mocno się spodobal, ale dodal, że mu marszałkowie powiadaja, że w Prusiech nędza wielka ${ }^{31 !}$.

Gerss z ukontentowaniem i dbałością stosunkowo najwięcej miejsca poświęcał zdarzeniom miejscowym, które odegrały raczej nikłą rolę w napoleońskiej epopei.

Mazurski pisarz, raz clıwaląc, raz ganiąc francuskiego cesarza, dokumentuje fakty świadczące o tym, że ofiarą jego militarnej polityki padl w Prusach przede wszystkim „lud”, czyli wiejska ludność cywilna. Twierdzit:

Napoleon, choć mądry, jednak się sparzył na pokrzywkach, po mazursku w żegawkach. Chcąc lud i kraj pruski do bankructwa przyprowadzić, to zostawił w Prusiech nie tylko wojsko, ale i niezliczonych urzędników i szpiegów francuskich, którzy na koszt Prusaków żyli, im zgoła spod

26. 'prawie' - prawdziwie, w rzeczywistości.

27 'przepowiadal' - dyktowal.

2* M. Gerss, O Napolconie..., op. cit., s. 102.

2) Ibidem, s. 114-115.

"Ibidem, s. 135. 
pazurów krew wyssali, wszystko, cokolwiek u nich znaleźli, pozabierali, a na koniec ostatny ich szeląg wyszperawszy, sobie przywłaszczyli.

I dalej:

Głupiej nie mógł Napoleon postępować, jak postępował.

I żaba skrzecze,

Kiedy na nią nadepce.

A Napoleon nadeptał na cały naród pruski nie byle. [...]. Od najwyższego pana, aż do najniższych stanów, rozpalili się wszyscy w Prusiech gniewem wielkim na Francuza, czekając czasu sposobnego, którego by się nad Napoleonem i nad calym narodem francuskim jak najśpieszniej pomścić się mogli. Krom ${ }^{31}$ wielkiej biady niewypowiedzianej, która nań przyszła, okazał się naród pruski jako dobroduszny, szlachetny, wierny i wytrwały, ponosząc niedostatek, ubóstwo i prześladowania na podziw z wielką cierpliwością ${ }^{32}$.

Gerss nie pozostawia złudzeń i wątpliwości: klęska Napoleona wyniknęła z nieprzestrzegania zasad morahnych, z jego „hardości i wyniosłości”, z zazdrości o władzę ale też bezlitosnych działań jego wojsk. Ich przemarsz przez Mazury rdzenna ludność okupiła dotkliwymi stratani. Np.:

Przemarsze Francuzów wprawiło miasto [Lec, dziś Giżycko] w bardzo wielką biadę. Po nieurodzaju roku 1811 nie było dosyć żywności; a Francuzom trzeba było wszystkiego poszafować ${ }^{3+}$. Ale skąd co wziąć? Francuzi pościnali więc niedorzeniałe ${ }^{35}$ zboże na polu przed ${ }^{36}$ konie swoje $^{37}$.

Podobne zdarzenia dotknęly wiele miejscowości na Mazurach: Wielbark, Pasym, Jeruty, Jerutki, Szczytno, Ządzbork [dziś Mrągowo], Jansbork, Ełk, Gołdap, Olecko, Reszel, Rastembork [dziś Kętrzyn] czy w Napiwodzie, gdzie żołnierze gen. Dominico Pino z dachów pościągali słomę, umościli sobie z niej barłogi.

W jednej chacie pustej, w której pełno było słomy, rozebrali piec żołnierzy, na którego jedzienie sobie warzyli. Przy tem zapaliła się chałupa

\footnotetext{
31 'krom' - oprócz.

32 M. Gerss, O Napoleonie.... op. cit., s. 1013-104.

3.. Zob. ibidem, s. 132-133.

3+ 'poszafować" — oddać za darmo.

35 "niedorzeniate' - niedojrzate.

36. "przed" - dla.

M. Gerss, O Napoleonic.... op. cit., s. 136.
} 
i skleszczała ${ }^{38}$, ale razem poszły wzgórę dymem wszystkie budynki dziesięciu gospodarzów ${ }^{3 !}$.

Gerss zrekonstruował pokrótce wypadki wojny francusko-rosyjskiej, włączając w narrację zwięzle opisy tragicznych zdarzeń - dzieło straszliwych mrozów i rozpętanej nienawiści. Na przedstawienia okrucieństw nałożył się w jakimś stopniu żywiony już w XIX w., a potem w XX lęk przed Rosjanami, a szczególnie Kozakami, np.:

Kozacy nieraz z Francuzami zmarzłymi nawet straszne figle stroili. Zastawili cztery i więcej Francuzów zmarzłych pospołu i powyciągali im ręce na różne strony, jak są u słupa drogę pokazującego. Do jednej ręki przypięli kartkę z napisem: „Do Moskwy!”, a do drugiej z napisem: „Do Paryża!”+".

Obrazy wynędzniałych wojsk francuskich Gerss pokazuje nie tyle z myślą o zemście, ile z niejaką litością, wspólczuciem, choć odnotowuje okrucieństwo zdemoralizowanych Francuzów na Mazurach już po odwrocie z Rosji:

Ci Francuzi, Włosi, Hyszpanie, Bawarczycy, Wirtembergczycy i inni, co z Napoleonem do Rosji ciągnąc, Prusaków z nimi sprzymierzonych, byli obrabowali, męczyli i hardzie, i okrutnie z nimi postępowali, wracali się przez Prusy w największej nędzy, wygłodniali, nadzy, chorzy, z członkami odmrożonymi i przyodziani byle jakimi łachmanami.

Pieszo, konno i na saniach wlokly się ostatki ogromnej armiji, po części bez koszuli, bez skorzen, czyli butów, bez sukmana, bez pończoch, po mazursku strefel z broni. Jenerałowie, oficerowie i proste żolnierze, pojedyńczo i w gromadach, wędrowali w nędzy wielkiej ku domowi.

Uciekinierzy obladowani ukradzionym w Rosji złotem i kosztownościami „w ciele swojem — jak pisze Gerss — mieli kieł strasznych chorób zaraźliwych"+1 — z tego powodu w miejscach ich postoju wybuchały epidemie. Mazurski pisarz niejako z autopsji czy opowiadań rodziców wspomina, że niektórzy Francuzi prosili Mazurów o gościnç. Do rodziców Gerssa we wsi Kowalki pod Goldapią ,jeden z Moskwy wracający siç Francuz przyszedł i o gościnę na parę tygodni prosił. Był zdrowy i mieszkał u nas 14 dni i dobrze się sprawowal" "2. Mazur odnotowal tez inne przykłady, kiedy to żołnierze Napoleona pozostawali w Prusach Wschodnich i żenili się z Mazurkami:

\footnotetext{
3x "skleszczeć" — zawalić się.

${ }^{39}$ M. Gerss, O Napolconic'..., op. cit., s. 138.

411 Ibidem, s. 145.

41 Ibidem, s, 152-153.

+2 Ibidem, s. 151 .
} 
Pewny rodzony Francuz — mnie się zdaje, że imię jego było Gillet — był inspektorem w Dorsach [Dorszach], w powiecie gołdapskim, należących czasu onego jenerałowi Wierzbickiemu w Gielweydach [Galwieciach]. I on się ożenil i dziatki z żoną spłodził. Był bardzo porządnym człowiekiem. Wydawca Kalendarza [Gerss] znał go i familią dobrze i nawiedził go raz w późniejszych latach ${ }^{+3}$.

W tamtym czasie wielu żołnierzy rozbitej armii Napoleona stało się włóczęgami, którymi mieszkańcy Prus pogardzali+ ${ }^{+}$.

Gerss stosunkowo dużo miejsca poświęcil feldmarszałkowi pruskiemu Johannowi Davidowi Ludwigowi Yorckowi, kreując go na jednego z bohaterów w dziejach Prus, mimo że jako sojusznik zdradził Napoleona. Niewierność i zdrada były na ogół przez Mazura potępiane, gdyż znajdowały się na antypodach uznanej w tradycji państwowości pruskiej cnoty lojalności.

Oprócz przez dziesiątki lat pisanego cyklu artykułów, których wybór znalazł się w książce O Napoleonie, nieszczęsliurej u'ojnie, dziejach europejskich i pruskich, Marcin Gerss ukladal wlasne wiersze o tematyce prusko-napoleońskiej. Są to: Pieśn o Prusaku i Francuzie, osobliure o u'ojnie r. 1813, 14. i 15. (,Kalendarz Królewsko-Pruski Ewangelicki” [dalej: KKPE] 1871, s. 81), napisana w 1868 r., a składająca się z 34. sześciowersowych strof. Utwór opowiada o przebiegu „wojny wyzwoleńczej”, zakończonej zwycięstwem przymierza antynapoleońskiego 18 czerwca 1815 r. pod Waterloo (Gerss chętniej stosował nazwę Belle Alliance). Piéśn o Prusaku i Francuzie opiera się na schemacie, w którym wojska pruskie triumfują militarnie nad zabitymi albo uciekającymi żołnierzami Napoleona.

Na motywach związanych z obecnością armii francuskiej w Prusach opiera się humoreska Marcina Gerssa pt. Jak Francuz francuzóu' '" Staréj Ukcie pod Ządzborkiem smaczno pozjadat (KKPE 1879, s. 85-86):

Czasu wojny raz Francuzi w Staréj Ukcie byli, I jak wszędzie, na koszt ludzi bardzo hojnie żyli. Czarny chlebek, który jemy, wcale za nic mieli, Lecz mialkiego i kołaczów i mięsiwa clıcieli.

A Ukcienie z całéj mocy się usiłowali, Aby Frankom, ile można, jak najlepièj dali.

Lecz Francuzów czasu tego, bardzo wielka siła, Takich, co po ścianach łażą, w Staréj Ukcie było. 
Które gromadami co dzień w jedzienie wpadały,

Że kobiety z wybieraniem wielką biadę miały.

U jednego gospodarza wpadlo w śliczną zupę,

Przed Francuza zgótowaną tyclı brzydaków kupę.

Ale Francuz zjadl je smaczno, że aż się oblizał,

Mówiąc, że to małe raki i palce oblizał.

Gdy nazajutrz tych francuzów z zupy wyłowili,

Prosil, żeby małych raków znowu uwarzyli.

Mowa tu o głodzie, jaki często trapił żołnierzy francuskich w Prusach. Gerss wykorzystał grę słów, wyraz „francuzy” bowiem oznaczał na Mazurach złośliwego owada domowego, którego częściej w języku polskiej bywa nazywany „prusakiem”. Wygłodzony Francuz, który zjadał ze smakiem zupę z garścią tych owadów i mylił je z „małymi rakami", wywołuje nie tylko politowanie, lecz i śmiech, zwlaszcza że Francuzi słyną jako smakosze i amatorzy dobrej kuchni. W tle pokazują się mazurscy chłopi w roli zmyślnych i przebiegłych ludzi, którzy potrafią wyprowadzić w pole chciwych Francuzów.

O Mazurze, który za pomocą fortelu wprowadzil w błąd żądnych szybkiego zysku i poszukujących skarbów żołnierzy francuskich, opowiada humorystyczna opowiastka Gerssa O rozumn'y'm gospodarzu u' Dzu'icrzutach (KKPE 1879, s. 84-85):

W latach nieszczęśliwéj wojny

Byl czas bardzo niespokojny.

Bo Francuzi u nas byli

I niemało lud dręczyli.

I gdzickolwiek w Prusiech stali,

To z kretesu obdzierali,

Zabierając dóbr niemało,

Że niewiele co zostało.

Ludzie rzeczy swe chowali, Nawet w ziem' zakopywali. Ale Francuz wsio wyszperal, A znalaztszy pozabierat.

Był w Dzwierzutach człek rozumny.

A ten rzekt: „Francuzie dumny,

Choć i jutro u mnie staniesz,

Jednak tu nic nie dostaniesz! 
I nie będzie żadna szkoda".

Wieczór poszedl do ogroda.

Tęgo wądół tam wykopał

I w nim skarby swe zakopal.

Przy nim zrobil wądół drugi,

Nie szeroki, ale długi.

Ziem, co z niego powyrzucal,

To na pierwszy wądół rzucał.

Bydło oddał w one strony,

Gdzie był ojciec jego żony.

Gdzie spokojnie wszyscy byli,

Gdyż Francuzi tam nic byli.

Rano przyszli Franki śmiele:

„Wiemy, że masz skarbów wiele.

Daj w dobroci je, gałganie!

Bo ci skóry dziś nie stanie!"

„Ach! panowie! Jestem goły.

Próżne chlewy i stodoly.

Nie man dzięgów, ani chleba,

Ani co do życia trzeba".

„Dość tych bajków, psie, gałganie!

Cierpliwości nam nie stanie.

Daj pieniędzy! Nie pleć wiele!

Bo ci zaraz w teb wystrzelę".

„Cy, panowie! Toć szukajcie,

Wszystkie kąty przetrząsajcie!

Darmo się poturbujecie,

Bo nic u mnie nie znajdziecie!"

I szukali, i szukali,

Każdy kat poprzewracali.

Ale wcale nic nie było,

Co by ich rozweseliło.

.Już dopiero widziem sami,

Żeś zakopal wsio przed nami.

Pokaż nam to miejsce, chłopie!

Bo cię zaraz za leb schopię!" 
„Czemuście się zapóźnili?

Już przed wami inni byli.

Wszystko mnie pozabierali.

Zgoła co nie wytrzepali!

Już nieszczęścia dosyć mialem.

Skarby w ziemię zakopałem.

Ale oni powąchali,

Wszystko z ziemi wykopali.

Pódźcież ze mną do ogroda,

Przeświadcież się, co za szkoda!

Swèmi uj̣rzycie oczyma,

Że już nic w wądole nie ma”.

W sadzie nad wądołem stali

I do niego zaglądali,

Mówiąc: „Głupiem postąpili,

Żeśmy się tak zapóźnilil!”

Temat napoleoński Gerss wplótł w dwukrotnie publikowany wiersz O mieście Moskuric po niemiecku Moskin (KKPE 1881, s. 136-138 i 1888, s. 108-110). Połowa utworu jest rymowaną relacją z klęski Napoleona i jego wojsk w Rosji 1812 r. Jego żałosny odwrót autor interpretuje jako karę od Boga:

I lezie Francuz zafrasowany,

Aż Pan Bóg zesłał mróz niesłychany.

Tak, że Francuzi z ciepléjszéj strony,

Pomarźli w drodze, jak chude wrony. [...]

Wszystko sprawila moc Najwyższego

I niezmierzona potęga Jego.

Jak dawniëj zniszczył Pan Faraona

Tak w nowszych czasach Napoleona.

Wiersz Gerss robił wrażenie na mazurskich czytelnikach, czego przejawem jest to, że około trzydzieści lat później inny poeta mazurski, Fryc Zimmek, ogłosil parafrazę tego utworu zatytułowaną Napoleon Bonaparte w' Rosyi roku 1812 (KKPE 1912, s. 148149). W setıą rocznicę wyprawy cesarza Francji na Rosję mazurski pastor Paul I Iensel (ostatni redaktor „Kalendarza Królewsko-Pruskiego Ewangelickiego”) nazwał ją apo- 
kaliptycznie „Sądem Bożym” ną mądrością, że „Bóg się pysznym sprzeciwia, ale pokornym laskę dawa”. Hensel, przypomniawszy przebieg wydarzeń $1812 \mathrm{r}$. i przeciwstawiwszy rzekomo niezwykle pobożnego Aleksandra I i jego bogobojny naród bezbożnemu, diabelskiemu Napoleonowi powrócil do wcześniej podnoszonych przez Mazurów motywów, np. braku szacunku do chleba u Francuzów:

Z tajnym gniewem musieli się Prusacy przypatrzeć temu, jak te rozpustne i swawolne zgraje w szalonej pysze świeży chleb pszenny gromadnie w błocie podeptali.

Zbezczeszczenie chleba było jednym z wielu objawów pychy i wyniosłości Francuzów. Najbardziej wstrząsające u Hensla są naturalistyczne, juz bez śladów współczucia, opisy powrotu trwale i straszliwie okaleczonych, wygłodniałych, zdziczalych, do cna zrozpaczonych żolnierzy Napoleona. Ponieśli oni według mazurskiego pastora zasłużoną karę — „Tu palec Boży!” - napisał.

Paul I Iensel, tak jak kilkadziesiąt lat przed nim Gerss, posiłkowal się cytatami z napoleońskich utworów Ernsta Moritza Arndta. Marcin Gerss w artykule O poctach lud do boju zachęcajq̨çch scharakteryzował sylwetki: Arndta, Friedricha Fouqué, Karla Theodora Körnera, przytaczając ich wiersze ${ }^{t h}$. Na podstawie niemieckich źródeł ułożył dwa moralistyczne opowiadania, które lagodzily ostry osąd o Napoleonie jako czlowieku nieczulym i niesprawiedliwym. Huzar " $N_{Y}$ sie (Neise) (KKPE 1880, s. 121-124) ilustruje tezę, że nie tylko Francuzi „licho gospodarowali” w Prusach w czasie „nieszczęśliwej wojny"; także Prusacy, walcząc na ziemi francuskiej, postępowali niezwykle bestialsko. Opowiadanie Cesarz Napoleon i handlarka "' Bricnnie (KKPE 1880, s. 124-127) idealizuje wodza Francuzów, pokazując go w sposób sentymentalny i wzruszający do łez, jako czlowieka, który potrafił być wdzięczny i za okazane dobro odplacić się stukrotnie.

Otto Gerss (bratanek Marcina), wzorując się na wierszu Arndta, ułożył pieśń pochwalną pt. Bitu'a pod Lipskiem (KKPE 1906, s. 161). Przywolywanie przez mazurskich pisarzy niemieckich poetów i historyków świadczy o tym, że pogląd na Napoleona i jego wojsk kształtowala obok rodzimej pamięć o historycznych zdarzeniach w rodzinnych stronach, pruska, a potem prusko-niemiecka literatura, historiografia, polityka i propaganda.

Spośród mazurskich autorów jedynie Gerss zdobył się na obwarowane różnymi zastrzeżeniami uznanie dla Napoleona. Można domniemywać, że w mazurskim pisarzu zachodziło wewnętrzne tarcie pomiędzy fascynacją Napoleonem i aprobatą dla jego niektórych poczynań a powinnościami i przekonaniami pruskiego patrioty. 
Marcin Gerss, który napisał setki panegirycznych wierszy i artykułów o królach pruskich, szczególnic w legendę (świecką hagiografiç) Wilhelma I wpisywał dzieje napoleońskie. W Krócinchnym opisie życia Najjaśniejjzégo cesarza niemieckiego i króla pruskiego Wilhelma I, który dnia 22 marca 1879 r. 82 lata uieku su'ojego dokoniczyt (KKPE 1880, s. 58-67), który składa się z 44 czterowersowych strof, o Napoleonie i jego wojsku Gerss pisze już tylko i wyłącznie źle. Patriotyzm pruski czy też już prusko-niemiecki wymuszał postawy jednoznaczne i bezdyskusyjne. 